Portland State University

PDXScholar

$11-2013$

\title{
Healthcare Utilization of Subgroups of Latinas: Shortfalls in Data Interpretation
}

Carlos J. Crespo

Portland State University, ccrespo@pdx.edu

Follow this and additional works at: https://pdxscholar.library.pdx.edu/commhealth_fac

Part of the Community Health Commons

Let us know how access to this document benefits you.

\section{Citation Details}

Crespo, Carlos J. "Healthcare Utilization of Subgroups of Latinas: Shortfalls in Data Interpretation." Journal of Women's Health 22.10 (2013): 877-877.

This Letter to the Editor is brought to you for free and open access. It has been accepted for inclusion in Community Health Faculty Publications and Presentations by an authorized administrator of PDXScholar. Please contact us if we can make this document more accessible: pdxscholar@pdx.edu. 


\title{
Healthcare Utilization of Subgroups of Latinas: Shortfalls in Data Interpretation
}

\author{
Carlos J. Crespo, DrPH, FACSM ${ }^{1}$
}

$\mathbf{I}_{\mathrm{r}}^{\mathrm{r}}$ FOUND THE ARTICLE BY Ai et al. ${ }^{1}$ to have the potential to contribute significantly to our understanding about the overall health and healthcare utilization of Latinos in the United States. The findings advance the field by using a welldescribed survey of Latinos who participated in the National Latino and Asian American Study (NLAAS) to crosssectionally identify differences among Cuban Americans, Mexican Americans, Puerto Ricans, and other Latinos. The authors provided an insightful discussion about potential explanations for the differences between subgroups of Latinos in the United States and potential variability according to place of birth. The investigators stated that this study may be among the first of its kind to present differences among major ethnic subgroups of Latino American women with respect to chronic conditions, and behavioral and mental health, using data from the first nationally representative sample of Latinos in the United States. While the authors acknowledge the limitation of self-reported data, they failed to recognize earlier and multiple findings from the Hispanic Health and Nutrition Examination Survey with a significantly larger sample size and more objective data points of the major three groups of Latinos in the United States than the NLAAS.

In addition, all Puerto Ricans, regardless of place of birth, are Americans. Even in Hispanic Health and Nutrition
Examination Survey, the three main groups studied and reported on were: Mexican Americans, Cuban Americans, and Puerto Ricans (not Puerto Rican Americans). This is a critical element for your readers and other researchers who will do research among Latino subgroups [should] understand.

\section{Disclosure Statement}

No competing financial interests exist.

\section{Reference}

1. Ai AL, Appel HB, Huang B, Lee, K. Overall health and healthcare utilization among Latino American women in the United States. J Womens Health. 2012;21:878-885.

Address correspondence to: Carlos J. Crespo, DrPH, FACSM

School of Community Health Portland State University

PO Box 751

Portland, OR 97219

E-mail: ccrespo@pdx.edu

${ }^{1}$ School of Community Health, Portland State University, Portland, Oregon. 